\title{
Involvement of serum HSP 70 in Guillain-Barré Syndrome: An exploratory study and a review of current literature
}

\author{
Aida Loshaj-Shala ${ }^{1,2}$, Ana Poceva Panovska ${ }^{1}$, Katerina Brezovska ${ }^{1}$, \\ Giangiacomo Beretta $^{3 *}$, Ljubica Suturkova ${ }^{1}$, Slobodan Apostolski ${ }^{4}$ \\ ${ }^{1}$ Faculty of Pharmacy, University Ss. Cyril and Methodius, Skopje, Macedonia \\ ${ }^{2}$ Department of Pharmacy, Faculty of Medicine, University Hasan Pristina, Pristina, Kosovo \\ ${ }^{3}$ Department of Pharmaceutical Sciences DISFARM, University of Milan, Milan, Italy \\ ${ }^{4}$ Outpatient Neurological Clinic "Apostolski”, Belgrade, Serbia
}

Received: September 2014; Accepted: January 2015

\begin{abstract}
The evolutionary conserved family of heat shock proteins (HSP) is responsible for protecting cells against different types of stress. Although the levels of HSP can be readily measured in serum, the levels of HSP 70 in patients Guillain-Barre Syndrome (GBS) have not been studied before. To this aim we investigate whether patients with GBS $(n=21)$ had altered serum HSP 70 levels compared to healthy controls $(\mathrm{HC}, \mathrm{n}=9)$ and to patients affected by other immune disorders such as multifocal motor neuropathy (MMN, $\mathrm{n}=4)$ and chronic inflammatory demyelinating polyneuropathy (CIDP, $\mathrm{n}=6)$. The highest HSP 70 value $(15.78 \pm 1.72 \mathrm{ng} / \mathrm{mL})$ was found in one patient in the GBS group, although we have found that serum HSP70 levels were significantly higher in 2 out of the 21 GBS patients $(9.5 \%)$. Hence, it is of interest to underline that the patient with the highest HSP70 level, had also the best recovery rate. More extensive research is required in order to support the hypothesis that HSP 70 serum concentration may be a useful biomarker for the prediction of remission outcome for GBS patients.
\end{abstract}

Key words: Serum Heat Shock Protein HSP 70, Guillain-Barré Syndrome (GBS), ELISA.

\section{Introduction}

Guillain-Barré syndrome (GBS) is an acute inflammatory disorder where patients experience muscle weakness in the arms and legs (tetraplegia) as well as loss of deep tendon reflexes (areflexia). Surveillance studies from widely scattered geographical areas indicate that the annual incidence rate of GBS per 100,000 subjects ranges from 0.6 to 1.9. Higher incidence for developing GBS is in elderly, although it may affect persons of all ages.

There is a general misunderstanding about GBS, which is considered as a disease with good prognosis, while up to $20 \%$ of GBS patients remain severely disabled and ap-

\footnotetext{
* giangiacomo.beretta@unimi.it
}

proximately $5 \%$ die in the western countries (Hughes et al., 2007). GBS is currently the most common cause of acute flaccid paralysis worldwide since the near-elimination of poliomyelitis (Yuki, 2012).

GBS is usually preceded by an infection. A number of infectious agents seems to induce GBS, but their relation to the disease remains unclear. Among them, only Campylobacter jejuni is firmly established as a causative agent of GBS (Godschalk et al., 2004). Almost 25-40\% of GBS patients report history of gastroenteritis induced by $C$. jejuni infection 1-3 weeks prior to GBS onset (Nyati and Nyati, 2013). However, only 1 in 1000 patients, who are exposed to Campylobacter infection, develops GBS.

Infections with $C$. jejuni are associated with antibodies against human gangliosides GM1, GM1b, GD1a and 
GalNAc-GD1a (Willison and Yuki, 2002; Godschalk et al., 2004; Hughes and Cornblath, 2005).

The induction of these auto-antibodies has been associated with molecular mimicry between human ganglioside and bacterial epitopes present on the surface of the bacterial lipooligosaccharide, at least in those cases with a preceding $C$. jejuni infection and presenting antibodies to gangliosides (Koski, 1997; Nyati and Nyati, 2013; Yuki et al., 1997; Yuki, 1997),

Beside anti-ganglioside antibodies, it is believed that the etiological factors of several autoimmune diseases can be mediated by proteins belonging to the heat shock proteins (HSP) family (Yonekura et al., 2004).

HSP were discovered by Ritossa on 1962, who observed a puffing pattern in Drosophila chromosomes after exposure to heat. Since then, several investigations indicated the importance of HSP in clinical context (De Maio et al., 2012).

HSP are a family of highly conserved proteins present in all prokaryote and eukaryote cells under normal physiological conditions, and their overexpression is induced after different types of physiological stress (Arispe et al., 2002). These proteins play a crucial role in functioning as chaperones to prevent protein misfolding and aggregation (Craig et al., 1993).

Although their primary known action is intracellular, HSP are released in the extracellular environment and, recently, HSP 60 and HSP 70 have been described in the peripheral circulation in normal individuals and patients (Hantschel et al., 2000; Pockley et al., 1999). Recent evidence suggest that extracellular HSP 70 activates the immune system resulting in an inflammatory cascade (De Maio, 2011).

HSP 70 can be considered as the most conserved of the HSP families. It includes the cytosolic and nuclear constitutive Hsc 70 (HSP 73) and the stress-inducible HSP 70 (HSP 72) proteins, the endoplasmic reticulum (ER) Bip(Grp78), and the mitochondrial mt-HSP 70 (Grp 75) protein (Brocchieri et al., 2008). HSP 70 has been the subject of particularly extensive studies because it exhibits different functions in accordance with its location; intracellular HSP 70 exerts cytoprotective functions as a chaperone protein, whereas extracellular HSP 70 exerts immunomodulatory functions that trigger immunological responses (danger signals) as well as tolerance responses. (Mansilla and Montalban, 2012)

Hence, HSP appears to provide a further link between infection and autoimmunity. Similarity between bacterial and mammalian (macro)molecules may lead to human antigenic response either through recognition of conserved epitopes or via cross-reactivity termed molecular mimicry (Pockley et al., 1999).

Considering autoimmune conditions, previous studies assumed the involvement of HSP 70 in the pathogenesis of autoimmune disorders such as Grave's disease (Ratanachaiyavong et al., 1991), Behcet's disease (Birtas-Atesog- lu et al., 2008) and multiple sclerosis (MS) (Mansilla and Montalban, 2012). Elevated levels of serum HSP70 was found in atherosclerosis (Nakhjavani et al., 2010), Behcet Disease (Birtas-Atesoglu et al., 2008), systematic sclerosis (Ogawa et al., 2008), diabetes (Nakhjavani et al., 2010) and hepatic diseases (Gehrmann et al., 2014)

Concerning GBS, Yonekura et al. (2004) showed that GBS patients shared higher IgG antibody titers against several families of HSP (HSP 27, HSP 60, HSP 70) in their CSFs. However, there are contradictory findings concerning antibody titers to HSP family in sera. Yonekura et al. (2004) didn't find sera antibody titers to HSP family with significant differences between GBS patients and healthy control, while Helgeland et al. (2010) found significantly higher anti-HSP 70 antibody concentrations in sera from patients with GBS. Also Zhang et al. (2009) have found increased level of HSP 70 in experimental autoimmune neuritis, a Guillain-Barré syndrome (GBS) model.

To facilitate investigations on the possible clinical relevance of immunoreactive proteins in the development of GBS, recently our research group investigated the profiles and immunoreactivity of proteins from human peripheral nerve (HPN) tissue, the main pathological target of the disease, and from $C$. jejuni (O:19). The main candidate proteins identified in HPN were HSP in the Mw range between $60 \mathrm{KDa}$ and $70 \mathrm{KDa}$. In $C$. jejuni identified proteins were from the family of chaperone/co-chaperone proteins (DnaJ, DnaK and HtpG) (Loshaj-Shala et al., 2015).

Microbial DnaK ( $70 \mathrm{kDa})$ and HPN HSP 70 share high sequence homology, and HSP 70 autoantibodies have been shown in the human CSF (Yonekura et al., 2004)and sera of GBS patients (Helgeland et al., 2010), C. jejuni DnaK ( 70 kDa). For these reasons, DnaK /HSP can be suggested as carriers of possible antigen contributing to the induction of GBS (Shala et al., 2015).

Based on these findings, the aim of this study was to investigate whether patients with GBS had altered serum HSP 70 levels compared to healthy controls and to patients affected by other immune disorders such as multifocal motor neuropathy (MMN) and chronic inflammatory demyelinating polyneuropathy (CIDP). The results are discussed in the light of the previous relevant scientific literature.

\section{Materials and methods}

\section{Patient and control sera}

Before the specific treatments were given, and within a week from onset, electrophysiological findings and sera were obtained from $n=21$ patients with GBS consisting of $n=10$ AIDP, $n=3$ AMAN and $n=8$ with undefined form of GBS (11 men and 10 women; mean age 39 years). As a disease control, sera was also obtained from 4 patients with MMN (4 men; mean age 45 years), and 6 CIDP ( 5 men and 1 woman; mean age 51.5 years). Serum samples that were used in this study were from the diagnosed patients at the 
Neurological Clinic in the Clinical Center of Serbia. Sera donated from $\mathrm{n}=9$ healthy donors were used as normal control. All patients and healthy volunteers consented to participate in this study.

\section{Experimental setup}

Serum HSP 70 concentrations were measured using a HSP 70 ELISA kit (Sigma - Aldrich, USA) according to manufacturer instructions. All serum samples were tested at a 1:5 dilution with sample diluent buffer component provided with the kit. All experiments were performed in duplicate. Optical density (OD) was measured at $450 \mathrm{~nm}$ using a plate reader (Victor X4, Perkin Elmer, USA). The minimum detectable dose of human HSP 70 was $2 \mathrm{ng} / \mathrm{mL}$. The coefficients of variation were $10 \%$ for intra-assay determinations and $12 \%$ for inter-assay determinations. All OD readings were within the calibration curve limits.

\section{Statistical analysis}

All data were expressed as mean and standard deviation (SD). Before statistical analysis, normal dis-tribution and homogeneity of the variances were tested. Associations between the experimental parameters were investigated using one-way ANOVA, and differences between groups considered significant when $\mathrm{P}$-value was $<0.05$. Statistical analysis was performed using the R-commander GUI for R (v. 3.1.3) (Fox, 2005).

\section{Results and discussion}

\section{HSP 70 determination and comparison with previous re- sults}

The demographic characteristics of patients are summarized in Table 1.

In Fig. 1 are reported the HSP 70 levels detected by ELISA in patients experiencing the acute stage of GBS, MMN, CIDP and in HC subjects.

The results indicated no statistically significant difference in their mean \pm standard deviation values (ANOVA, $\mathrm{P}>0.05)$.
The highest HSP 70 value was found in one patient in the GBS group $(15.78 \pm 1.72 \mathrm{ng} / \mathrm{mL})$.

Table 2 shows a comparison of the HSP 70 levels found in our cohort of GBS patients compared to those reported for patients affected by other diseases, based on data reported by previous studies.

The mean levels reported in the present study were comparable with those reported for different liver conditions by (Gehrmann et al., 2014), while those reported by the other authors seemed to be lower depending on the reference study. Whether these differences may arise from the different patients demographic and genetic characteristics or from study-to-study differences in ELISA assay experimental set-up remains to be established.

Previously we investigated the profiles and immunoreactivity of peripheral nerve proteins and of $C$. jejuni, and reported that the main candidate proteins identified in the Mw range $60-70 \mathrm{KDa}$ where chaperone proteins of the HSP 70 family, and bacterial DnaK, GroEl and HtpG respectively (Loshaj-Shala et al., 2015).

In the present study we found that the serum levels of HSP 70 in sera from GBS patients where comparable with those found in $\mathrm{HC}$ and other autoimmune disorders.

However, 2 out of the 21 GBS patients (9.5\%) had higher HSP 70 level and it is of interest to underline that the patient with the highest HSP 70 level, had also the best recovery rate.

Extracellular HSP have been shown to act as potent immunostimulatory or immunosuppressive agents depending on the circumstances in which they interact with cells (Pockley et al., 2008).

De Maio, (1999) and Giffard et al. (2008) reported that the presence of HSP is important for the recovery from stress and protection from subsequent insults.

The importance of extracellular HSP has been emphasized by the detection of HSP 70 in the serum of patients suffering from an array of conditions and several autoimmune disorders. Among them, have been reported Grave's disease (Ratanachaiyavong et al., 1991), multiple sclerosis (MS) (Mansilla and Montalban, 2012), coronary artery diseases (Zhu et al., 2003), Behcet disease (BirtasAtesoglu et al., 2008), systematic sclerosis (Ogawa et al., 2008), diabetes (Nakhjavani et al., 2010) and hepatic dis-

Table 1. Demographic characteristics of patients. GBS: Guillain-Barré syndrome; CIDP: chronic inflammatory demyelinating polyneuropathy; MMN: multifocal motor neuropathy; HC: healthy controls

\begin{tabular}{cccc} 
Diagnosis & $\begin{array}{c}\text { No. of patients/sub- } \\
\text { jects }\end{array}$ & Age & Gender (M/F) \\
\hline GBS & 21 & $23-55$ & $11 / 10$ \\
CIDP & 6 & $35-68$ & $5 / 1$ \\
MMN & 4 & $32-58$ & $4 / 0$ \\
HC & 9 & $28-34$ & $5 / 4$ \\
\hline
\end{tabular}

Макед. фарм. билт., 61 (1) 61 - 67 (2015) 


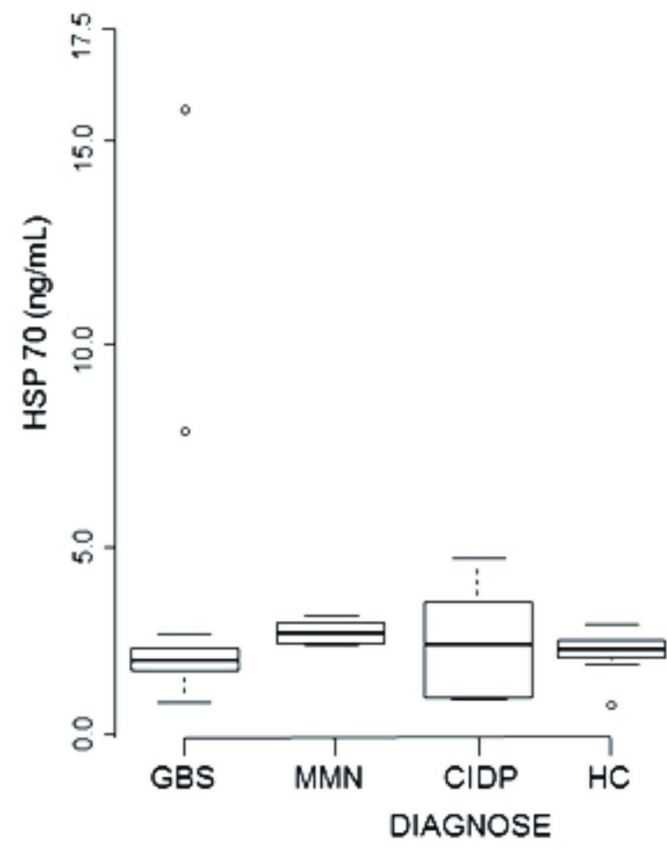

Fig. 1. HSP 70 serum levels detected in patients experiencing the acute phase of the Guillain-Barre syndrome patients (GBS, $\mathrm{n}=21$ ), multifocal motor neuropathy (MMN, $\mathrm{n}=4$ ), chronic inflammatory demyelinating polyneuropathy $(\mathrm{CIDP}, \mathrm{n}=6)$ and in healthy control subjects $(\mathrm{HC}, \mathrm{n}=9)$.

Table 2. HSP 70 serum levels in patients from different previously reported clinical studies N.R.: not reported
Disease
Disease $(\mathrm{ng} / \mathrm{mL})$
Control (ng/mL)
Reference

\begin{tabular}{|c|c|c|c|}
\hline Behçet Disease & $1.12 \pm 0.86($ mean $\pm \mathrm{SD})$ & $0.67 \pm 0.46($ mean $\pm \mathrm{SD})$ & Birtas-Atesoglu et al., 2008 \\
\hline Diabetes & $\begin{array}{l}0.70 \\
0.81-0.59 \text { (range) }\end{array}$ & $\begin{array}{l}0.23 \\
0.30-0.22 \text { (range) }\end{array}$ & Nakhjavani et al., 2010 \\
\hline $\begin{array}{l}\text { Hepatocellular carcinoma } \\
\text { (HCC) } \\
\text { Liver cirrhosis (LC) } \\
\mathrm{B} / \mathrm{C} \text { viral infection } \mathrm{CH}\end{array}$ & $\begin{array}{l}6.5-3.1 \text { (range) } \\
6.6-5.2 \\
3.9-2.4\end{array}$ & $2.7 \pm 0.9($ mean $\pm \mathrm{SD})$ & Gehrmann et al., 2014 \\
\hline $\begin{array}{l}\text { Coronary artery disease } \\
\text { (CAD) }\end{array}$ & $\begin{array}{l}0.5 \text { (median) } \\
27.1-0.2 \text { (range) all subjects } \\
0.34 \quad \text { (median) } \quad \mathrm{P}=0.0006 \\
(\mathrm{CAD} \text { vs. non } \mathrm{CAD})\end{array}$ & 0.72 (median, non CAD) & Zhu et al., 2003 \\
\hline Asthma & $\begin{array}{l}0.46 \text { (median) } \\
0.20-0.98 \text { (range) }\end{array}$ & $\begin{array}{l}0.14 \text { (median) } \\
0.11-0.37 \text { (range) }\end{array}$ & Hou et al., 2011 \\
\hline Chronic Fatigue Syndrome & $0.58 \pm 0.16$ & $1.64 \pm 0.18$ & Jammes et al., 2012 \\
\hline Vascular Calcification & $0.63(0.52-0.81)$ & N.R. & $\begin{array}{l}\text { Krepuska et al., 2011as well } \\
\text { as to markers of inflammation } \\
\text { (C-reactive protein }\end{array}$ \\
\hline GBS & $\begin{array}{l}3.101 \pm 3.27(\text { mean } \pm \mathrm{SD}) \\
2.208 \text { (median) } \\
1.18-15.78(\text { range })\end{array}$ & $\begin{array}{l}2.43 \pm 0.58(\text { mean } \pm S D) \\
2.5 \text { (median) } \\
1.12-3.1 \text { (range) }\end{array}$ & Current study \\
\hline
\end{tabular}

eases (Gehrmann et al., 2014). Krepuska et al. (2011) reported that serum level of soluble Hsp70 is associated with vascular calcification.
Zhang et al. (2009) reported increased levels of HSP 70 in an experimental model of autoimmune neuritis resembling GBS. 
HSP have been found also in the serum of apparently healthy individuals (Xiao et al., 2003).

The presence of HSP 70 in circulation has been correlated with improved survival of critically ill patients. Pittet et al. (2002) reported that HSP 72 can be detected in the serum of severely traumatized patients within 30 minutes after injury. Elevated initial serum levels of HSP 72 are associated with survival after severe trauma, but are not related to the incidence or severity of the post injury inflammatory response or organ dysfunction.

Ziegler et al., (2005) also investigated the role of HSP70 in survival of patients in critical stage. These authors observed that parenteral glutamine administration significantly increases serum HSP 70 and that the magnitude of HSP 70 enhancement was correlated with improved clinical outcomes in patients treated with glutamine.

Regarding the protective role of HSP 70, May et al. (2013) reported that HSP 70 release from supporting cells is necessary and sufficient to protect mechanosensory hair cell neurons from the toxic effects of aminoglycoside antibiotics, which is of broad importance, as there are currently no known ways to reduce the toxicity of this class of antibiotics.

The authors demonstrated that the release of HSP 70 from the glia-like supporting cells settled at the base of the hair cells leads to this protection, indicating two central findings: first, the neighboring glial cells release the HSP 70 that provides protection. Second, the extracellular HSP 70 appears sufficient to protect the neurons, without requiring significant uptake. These findings points to a critical role for signaling by HSP 70, rather than its established function as a direct molecular chaperone.

The work extends the broader understanding of the role of extracellular HSP 70 as a molecule for transmission of signals from one cell to another, likely through binding to cell surface receptors. The receptor for HSP70 in this setting is currently unknown (May et al., 2013).

Psychological stress and exercise that do not induce substantial cell death, lead to significant increases in extracellular HSP 70 (Giffard et al., 2013).

Furthermore, May et al. (2013) suggested the possibility that defective chaperone secretion or function could directly contribute to hear loss/balance disturbance if the hair cell is not protected. Similar consequences appears in other conditions in which defective chaperones contribute to pathogenesis (Macario and de Macario, 2005)

Tidwell et al. (2004) reported very promising results about the remedying properties of Hsc/HSP 70 in reducing the loss of neurons after exogenous administration in neonatal mouse. The authors examined the regulation of the constitutive and stress-induced 70-kD HSP (Hsc 70 and HSP 70, respectively) after sciatic nerve (SN) axotomy in the neonatal mouse. They found that endogenous levels of Hsc70 and HSP 70 did not increase significantly in lumbar motor neurons or dorsal root ganglion sensory neurons up to 24 hours after axotomy. However, after administra- tion of HSP 70 preparations to the SN stump after axotomy, the survival of both motor and sensory neurons was significantly improved. These results support the hypothesis that immediate application of exogenous Hsc 70 or HSP 70, or both, may be physiologically similar to induced synthesis of endogenous HSP 70 and can increase survival of damaged neurons.

Thus, Hsc70 and HSP 70 as new therapeutical agents in the prevention of immunologically mediated neurodegeneration need to be further studied.

\section{Conclusion}

In the present study, extracellular HSP 70 was monitored in the serum of patients with GBS and other neurological immune mediated diseases MMN, and CIDP.

The mean HSP 70 serum levels didn't show significant variations among these groups. The positive correlation with disease remission in two patients with GBS carrying the highest HSP 70 concentrations, although limited to a low number of patients, are supportive of a peripheral neuroprotective role of extracellular HSP 70, in good accordance to the results from several studies reported in the literature.

Our data encourage us to hypothesize that HSP 70 serum concentration may be a useful biomarker for the prediction of remission outcome for GBS patients. However, additional detailed studies involving a higher number of patients are necessary to confirm this hypothesis.

\section{Acknowledgments}

This work was in part supported by a grant from Santefarm (Pristina, Kosovo).

\section{Disclosure}

All the authors declare no disclosures.

\section{Author contributions}

A. L-S. and L. S. conceived the study design, participated in its design and in the management of sample collection and acquisition of data. A. L-S. and A. P. P. carried out the experiments, participated in the sample collection, acquisition of data, analysis and interpretation, and drafting of the manuscript. G. B. helped to analyze data and previous literature and to draft and revise the manuscript text, tables and figures. K. B. helped in sample management. S.A. did neurological assessment and diagnosis of patients and provided the samples. All authors read and approved the final submitted version of the manuscript. 


\section{References}

Arispe, N., Doh, M., De Maio, A., 2002. Lipid interaction differentiates the constitutive and stress-induced heat shock proteins Hsc70 and Hsp70. Cell Stress Chaperones 7, 330338.

Birtas-Atesoglu, E., Inanc, N., Yavuz, S., Ergun, T., D.H., 2008. Serum levels of free heat shock protein 70 and anti-HSP70 are elevated in Beh?et's disease. Clin. Exp. Rheumatol. 26, 96-98.

Brocchieri, L., Conway de Macario, E., Macario, A.J.L., 2008. hsp70 genes in the human genome: Conservation and differentiation patterns predict a wide array of overlapping and specialized functions. BMC Evol. Biol. 8, 19.

Craig, E., Gambill, B.D., Nelson, R.J., 1993. Heat shock proteins: molecular chaperones of protein biogenesis. Microbiol. Rev. 57, 402-414.

De Maio, A., 1999. Heat shock proteins: facts, thoughts, and dreams. Shock 11, 1-12.

De Maio, A., 2011. Extracellular heat shock proteins, cellular export vesicles, and the Stress Observation System: A form of communication during injury, infection, and cell damage: It is never known how far a controversial finding will go! Dedicated to Ferruccio Ritossa. Cell Stress Chaperones 16, 235-249.

De Maio, A., Gabriella Santoro, M., Tanguay, R.M., Hightower, L.E., 2012. Ferruccio Ritossa's scientific legacy 50 years after his discovery of the heat shock response: A new view of biology, a new society, and a new journal. Cell Stress Chaperones 17, 139-143.

Fox, J., 2005. The R Commander: A Basic-Statistics Graphical User Interface to R. J. Stat. Softw. 14, 1-42.

Gehrmann, M., Cervello, M., Montalto, G., Cappello, F., Gulino, A., Knape, C., Specht, H.M., Multhoff, G., 2014. Heat shock protein 70 serum levels differ significantly in patients with chronic hepatitis, liver cirrhosis, and hepatocellular carcinoma. Front. Immunol. 5, 307.

Giffard, R.G., Han, R.-Q., Emery, J.F., Duan, M., Pittet, J.F., 2008. Regulation of apoptotic and inflammatory cell signaling in cerebral ischemia: the complex roles of heat shock protein 70. Anesthesiology 109, 339-348.

Giffard, R.G., Macario, A.J.L., De Macario, E.C., 2013. The future of molecular chaperones and beyond. J. Clin. Invest. 123, 3206-3208.

Godschalk, P.C.R., Heikema, A.P., Gilbert, M., Komagamine, T., Wim Ang, C., Glerum, J., Brochu, D., Li, J., Yuki, N., Jacobs, B.C., Van Belkum, A., Endtz, H.P., 2004. The crucial role of Campylobacter jejuni genes in anti-ganglioside antibody induction in Guillain-Barré? syndrome. J. Clin. Invest. 114, 1659-1665.

Hantschel, M., Pfister, K., Jordan, a, Scholz, R., Andreesen, R., Schmitz, G., Schmetzer, H., Hiddemann, W., Multhoff, G., 2000. Hsp70 plasma membrane expression on primary tumor biopsy material and bone marrow of leukemic patients. Cell Stress Chaperones 5, 438-442.

Helgeland, G., Petzold, A., Hoff, J.M., Gilhus, N.E., Plant, G.T., Romi, F.R., 2010. Anti-Heat Shock Protein 70 antibody levels are increased in myasthenia gravis and GuillainBarré? syndrome. J. Neuroimmunol. 225, 180-183.

Hou, C., Changchun, H., Zhao, H., Haijin, Z., Li, W., Wenjun, L., Liang, Z., Zhenyu, L., Zhang, D., Dan, Z., Liu, L., Laiyu, L., Tong, W., Wancheng, T., Cai, S.-X., Shao-Xi, C., Zou,
F., Fei, Z., 2011. Increased heat shock protein 70 levels in induced sputum and plasma correlate with severity of asthma patients. Cell Stress Chaperones 16, 663-671.

Hughes, R.C., Cornblath, D.R., 2005. Guillain-Barré syndrome. Lancet 366, 1653-1666.

Hughes, R.C., Swan, A. V, Raphaël, J.-C., Annane, D., van Koningsveld, R., van Doorn, P., 2007. Immunotherapy for Guillain-Barré syndrome: a systematic review. Brain 130, 2245-2257.

Jammes, Y., Steinberg, J.G., Delliaux, S., 2012. Chronic fatigue syndrome: Acute infection and history of physical activity affect resting levels and response to exercise of plasma oxidant/antioxidant status and heat shock proteins. J. Intern. Med. 272, 74-84.

Koski, C.L., 1997. Mechanisms of Schwann cell damage in inflammatory neuropathy. J. Infect. Dis. 176, S169-S172.

Krepuska, M., Szeberin, Z., Sótonyi, P., Sarkadi, H., Fehérvári, M., Apor, A., Rimely, E., Prohászka, Z., Acsády, G., 2011. Serum level of soluble Hsp 70 is associated with vascular calcification. Cell Stress Chaperones 16, 257-265.

Loshaj-Shala, A., Regazzoni, L., Daci, A., Orioli, M., Brezovska, K., Panovska, A.P., Beretta, G., Suturkova, L., 2015. Guillain Barr? syndrome (GBS): new insights in the molecular mimicry between C. jejuni and human peripheral nerve (HPN) proteins. J. Neuroimmunol. 289, 168-176.

Macario, A., de Macario, E.C., 2005. Sick chaperones, cellular stress, and disease. N. Engl. J. Med. 353, 1489-1501.

Manouchehr Nakhjavani, Afsaneh Morteza, Leila Khajeali, Alireza Esteghamati, Omid Khalilzadeh, Firouzeh Asgarani, T.F.O., 2010. Increased serum HSP70 levels are associated with the duration of diabetes. Cell Stress Chaperones 15, 959-964.

Mansilla, M., Montalban, X., 2012. Heat Shock Protein 70: Roles in Multiple Sclerosis. Mol. Med. 18, 1018-1028.

May, L., Kramarenko, I.I., Brandon, C.S., Voelkel-Johnson, C., Roy, S., Truong, K., Francis, S.P., Monzack, E.L., Lee, F.S., Cunningham, L.L., 2013. Inner ear supporting cells protect hair cells by secreting HSP70. J. Clin. Invest. 123, 35773587.

Nakhjavani, M., Morteza, A., Khajeali, L., Esteghamati, A., Khalilzadeh, O., Asgarani, F., Outeiro, T.F., 2010. Increased serum HSP70 levels are associated with the duration of diabetes. Cell Stress Chaperones 15, 959-964.

Nyati, K.K., Nyati, R., 2013. Role of Campylobacter jejuni infection in the pathogenesis of Guillain-Barré syndrome: an update. Biomed Res. Int. 2013, 852195.

Ogawa, F., Shimizu, K., Hara, T., Muroi, E., Hasegawa, M., Takehara, K., Sato, S., 2008. Serum levels of heat shock protein 70, a biomarker of cellular stress, are elevated in patients with systemic sclerosis: association with fibrosis and vascular damage. Clin. Exp. Rheumatol. 26, 659-662.

Pittet, J.F., Lee, H., Morabito, D., Howard, M.B., Welch, W.W., Mackersie, R.C., 2002. Serum levels of Hsp 72 measured early after trauma correlate with survival. J Trauma. 2002 Apr;52(4)611-7; Discuss. 617. 52, 611-617.

Pockley, A.G., Muthana, M., Calderwood, S.K., 2008. The dual immunoregulatory roles of stress proteins. Trends Biochem Sci. 33, 71-79.

Pockley, G., Bulmer, J., Hanks, B.M., Wright, B.H., 1999. Identification of human heat shock protein 60 (Hsp60) and anti-Hsp60 antibodies in the peripheral circulation of normal individuals. Cell Stress Chaperones 4(1), 29-35.

Ratanachaiyavong, S., Demaine, A.G., Campbell, R.D., 
Mcgregor, A.M., 1991. Heat shock protein 70 (HSP70) and complement $\mathrm{C} 4$ genotypes in patients with hyperthyroid Graves' disease. Clin. Exp. Immunol. 70, 48-52.

Tidwell, J.L., Houenou, L.J., Tytell, M., 2004. Administration of Hsp70 in vivo inhibits motor and sensory neuron degeneration. Cell Stress Chaperones 9, 88-98.

Willison, H.J., Yuki, N., 2002. Peripheral neuropathies and antiglycolipid antibodies. Brain 125, 2591-2625.

Xiao, C., Wu, T., Ren, A., Pan, Q., Chen, S., Wu, F., Li, X., Wang, R., Hightower, L.E., Tanguay, R.M., 2003. Basal and inducible levels of Hsp70 in patients with acute heat illness induced during training. Cell Stress Chaperones 8, 86-92.

Yonekura, K., Yokota, S.I., Tanaka, S., Kubota, H., Fujii, N., Matsumoto, H., Chiba, S., 2004. Prevalence of anti-heat shock protein antibodies in cerebrospinal fluids of patients with Guillain-Barré syndrome. J. Neuroimmunol. 156, 204 209.

Yuki N, Taki T, Inagaki F, Kasama T, Takahashi M, Saito K, Handa S, M.T., 1997. A bacterium lipopolysaccharide that elicits Guillain-Barré syndrome has a GM1 ganglioside-like structure. J. Exp. Med. 178, 1771-1775.
Yuki, N., 2012. Guillain-Barré syndrome and anti-ganglioside antibodies: a clinician-scientist's journey. Proc. Jpn. Acad. Ser. B. Phys. Biol. Sci. 88, 299-326.

Yuki, N., 1997. Molecular mimicry between gangliosides and lipopolysaccharides of Campylobacter jejuni isolated from patients with Guillain-Barré syndrome and Miller Fisher syndrome. J. Infect. Dis. 176 Suppl, S150-S153.

Zhang, Z.Y., Zhang, Z., Schluesener, H.J., 2009. Toll-like receptor-2, CD14 and heat-shock protein 70 in inflammatory lesions of rat experimental autoimmune neuritis. Neuroscience 159, 136-142.

Zhu, J., Quyyumi, a. a., Wu, H., Csako, G., Rott, D., ZallesGanley, a., Ogunmakinwa, J., Halcox, J., Epstein, S.E., 2003. Increased Serum Levels of Heat Shock Protein 70 Are Associated With Low Risk of Coronary Artery Disease. Arterioscler. Thromb. Vasc. Biol., 23(6), 1055-1059.

Ziegler, T.R., Ogden, L.G., Singleton, K.D., Luo, M., FernandezEstivariz, C., Griffith, D.P., Galloway, J.R., Wischmeyer, P.E., 2005. Parenteral glutamine increases serum heat shock protein 70 in critically ill patients. Intensive Care Med. 2005 Aug;31(8)1079-86. 31, 1079-1086.

\title{
Резиме
}

\section{Улога на серумскиот HSP 70 во Guillain-Barré синдромот: Прелиминарни истражувања и преглед на литература}

\author{
Аида Лошај-Шала ${ }^{1,2}$, Ана Поцева-Пановска' ${ }^{1}$, Катерина Брезовска ${ }^{1}$, \\ Џанџакомо Берета ${ }^{3 *}$, Љубица Шутуркова ${ }^{1}$, Слободан Апостолски ${ }^{4}$

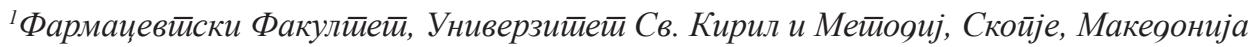

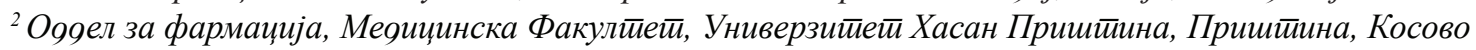

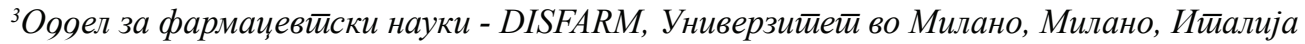 \\ ${ }^{4}$ Амбуланйно невролошка клиника „Айосӣолски“, Белірая, Србија
}

Клучни зборови: серумски Heat Shock протеин 70 (HSP 70), Guillain-Barré синдром (GBS), ELISA

Heat shock протеините (HSP) како еволуциски конзервираната фамилија на протеини учествува во заштитата на клетките при различни видови на стрес. Нивото на протеинот HSP 70 во серуми од пациенти co Guillain-Barre синдром (GBS) не е истражено. Целта на оваа студија е да се определи нивото на HSP 70 во серуми од пациенти co Guillain-Barre синдром (GBS, $\mathrm{n}=21$ ) и да се спореди со нивото на овој протеин во серуми од здрави доброволци $(\mathrm{HC}, \mathrm{n}=9)$ како и во серуми од пациенти со други невролошки заболувања, како мултифокална моторна невропатија (MMN, n=4) и хронична инфламаторна демиенилизирачка полиневропатија (CIDP, n=6). 
